\title{
Jehu's violent coup and the justification of violence
}

\begin{tabular}{|c|c|}
\hline \multicolumn{2}{|c|}{$\begin{array}{l}\text { Authors: } \\
\text { Lerato L.D. Mokoena }^{1} \text { (D) } \\
\text { Esias E. Meyer }{ }^{1} \text { (D) }\end{array}$} \\
\hline \multicolumn{2}{|c|}{$\begin{array}{l}\text { Testament Studies, Faculty of } \\
\text { Theology and Religion, } \\
\text { University of Pretoria, } \\
\text { Pretoria, South Africa }\end{array}$} \\
\hline \multicolumn{2}{|c|}{$\begin{array}{l}\text { Research Project Registration: } \\
\text { Project Leader: Esias E. Meyer } \\
\text { Project Number: } 02364743\end{array}$} \\
\hline \multicolumn{2}{|c|}{$\begin{array}{l}\text { Description: } \\
\text { Lerato Mokoena is } \\
\text { participating in the research } \\
\text { project, 'The justification of } \\
\text { violence in Hebrew narratives } \\
\text { from the Former Prophets', } \\
\text { directed by Prof. Dr Sias } \\
\text { Meyer, Department of Old } \\
\text { Testament Studies, Faculty of } \\
\text { Theology and Religion, } \\
\text { University of Pretoria. }\end{array}$} \\
\hline \multicolumn{2}{|c|}{$\begin{array}{l}\text { Corresponding author: } \\
\text { Esias Meyer, } \\
\text { sias.meyer@up.ac.za }\end{array}$} \\
\hline \multicolumn{2}{|c|}{$\begin{array}{l}\text { Dates: } \\
\text { Received: } 13 \text { Nov. } 2018 \\
\text { Accepted: } 24 \text { Feb. } 2019 \\
\text { Published: } 23 \text { Apr. } 2019\end{array}$} \\
\hline \multicolumn{2}{|c|}{$\begin{array}{l}\text { How to cite this article: } \\
\text { Mokoena, L.L.D. \& Meyer, E.E., } \\
\text { 2019, 'Jehu's violent coup } \\
\text { and the justification of } \\
\text { violence', HTS Teologiese } \\
\text { Studies/Theological Studies } \\
\text { 75(3), a5326. https://doi.org/ } \\
\text { 10.4102/hts.v75i3.5326 }\end{array}$} \\
\hline \multicolumn{2}{|c|}{$\begin{array}{l}\text { Copyright: } \\
\text { (C) 2019. The Authors } \\
\text { Licensee: AOSIS. This } \\
\text { is licensed under the } \\
\text { Creative Commons } \\
\text { Attribution License. }\end{array}$} \\
\hline \multicolumn{2}{|l|}{ Read online: } \\
\hline 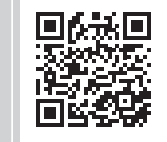 & $\begin{array}{l}\text { Scan this QR } \\
\text { code with your } \\
\text { smart phone or } \\
\text { mobile device } \\
\text { to read online. }\end{array}$ \\
\hline
\end{tabular}

The putsch carried out by Jehu is one of the most violent stories in the Hebrew Bible. The text justifies the violence by portraying the rebellion as a case of retributive justice for the death of Naboth and as an attempt to purify Yahwism. This article presents a critical reading of the text as well as an overview of how the interpretation of the text changed after the discovery of the Tel Dan inscription. The article also presents recent views on the history of Yahwism and finally presents the story as a (failed) attempt to justify a coup that was probably only about acquiring power.

Keywords: Violence; Jehu; Tel Dan; Yahwism; Naboth.

\section{Introduction}

The narrative of 2 Kings 9-10, like many other narratives in the Old Testament, tells a disturbingly violent tale. This story is part of what was once called the Deuteronomistic History (DH), and there are obviously other violent narratives in the $\mathrm{DH}$ as well, ${ }^{1}$ of which the foremost would probably be the story of conquest in the book of Joshua. ${ }^{2}$ Then there is also the book of Deuteronomy, with a legal code (Dt 12-26) at its heart that includes, according to Scheffler (2014:582-588), laws that are very violent. ${ }^{3}$ Yet, the actions of the usurper Jehu, when compared to those just referred to, seem particularly violent. In 2 Kings 9, after killing his boss Joram, king of Israel, and throwing his body to the ground (v. 25), Amaziah, king of Juda, is also killed (v. 27). Jezebel is next and is thrown off her tower in Jezreel, where the dogs eat most of her (vv. 33-37). This takes us to 2 Kings 10, where the murder spree is scaled up from individuals to groups. The sons of Joram follow, with all 70 of them beheaded by their caretakers and their heads placed in baskets, which are then used to coerce these caretakers into following Jehu (vv. 7-9). On the way to Samaria, Jehu runs into relatives of Amaziah, who are also killed, all 42 of them (v. 14). In Samaria, Jehu kills 'all who were left to Ahab in Samaria, until he had wiped them out' (New Revised Standard Version, v. 17), but this is not the end yet. In verses 18-28, Jehu deceives the worshippers of Baal and eventually kills all of them.

The text itself presents a very positive image of Jehu, which is exceptional for a northern king (Lamb 2007:1). ${ }^{4}$ The story provides two basic reasons for the bloodbath and both have to do with the prophets Elijah and Elisha, although at this stage in the narrative the former has left, and the latter has succeeded him. One reason for all the killings could be described as a desire for 'justice' or 'revenge', and has to do with Ahab, the father of Joram, taking the vineyard of Naboth in 1 Kings 21. Elijah played a key role in that narrative, especially when he cursed Ahab and Jezebel, and so what happens subsequently to both Joram and Jezebel is linked to that incident. The other reason offered in the text is especially clear in 10:18-28 and has to do with the worship of Baal. What Jehu does here evokes what Elijah did to the Baal prophets in 1 Kings 18. Furthermore, Elisha triggered all these murderous events by sending one of his students to anoint Jehu as king at the beginning of 2 Kings 9. Traditionally, many scholars have followed the text and argued that these grounds of seeking justice and preserving religious purity somehow explained or even justified the extreme violence used in the story. ${ }^{5}$ These scholars argued, for example, that 1.The authors are familiar with the recent debate on the Deuteronomistic History. We do not subscibibe to either of the two prevailing
schools, but use the term 'Deuteronomistic History' rather loosely, with Deuteronomist (Dtr) referring to the authors and editors of the
work. For a concise overview of the debate, see Römer (2013).

2.See an extensive discussion in Meyer (2011).

3.Thus, the authors present this article for this Festschrift for Eben Scheffler to acknowledge his contribution to the debate on the Bible and violence.

4.Lamb (2007:1) describes Jehu as the only northern ruler, who is described as 'righteous, as anointed, or as a recipient of an unconditional dynastic promise'. See also Lamb (2007:22-26).

5.See the extensive list of scholars provided by White (1997:1). In her published PhD thesis, which was written before the discovery of the Tel Dan inscription, she sets out to refute these opinions, which she regards as proceeding from an 'overly literal reading' of the text.

Note: The collection entitled 'Eben Scheffler Festschrift', sub-edited by Jurie H. le Roux (University of Pretoria) and Christo Lombaard (University of South Africa). 
'there was a mid-ninth century prophetic "revolution" linked with the Jehu-led "revolt" against the "oppressive" house of Omri, implying a broad popular base for the "revolt"' (White 1997:1). This implies that the violence is somehow more palatable because, in modern-day parlance, it was 'the will of the people' and it was done for the sake of YHWH and justice. The problem for the contemporary reader is that when violence is attributed to and allegedly sanctioned by a deity, it could potentially incite more violence, something that our world has already had more than enough of.

In the rest of the article, we will try to show how the discovery of the Tel Dan inscription changed the way in which we could interpret 2 Kings 9-10 and how, in a sense, it made things worse, if one is concerned with the violence in an ancient text. Before Tel Dan, many scholars could still argue that the violence was 'justified' because of the quest for purer Yahwism, or because of retributive justice as restitution for Ahab's sin in the story of Naboth's vineyard. ${ }^{6}$ There were scholars who presented more critical readings of this story, as we will see in a moment. Yet, after the discovery at Tel Dan, if one agrees with most scholars' interpretation of who wrote the Tel Dan inscription, then Jehu just becomes another opportunist who might have been in cahoots with a foreign king.

\section{The stories and their discrepancies}

One of the major textual issues when comparing 1 Kings 21 with 2 Kings 9-10 is the interesting discrepancies between the words of Jehu as justification for killing the king in 2 Kings 9:21-26 and the story of Naboth's vineyard. ${ }^{7}$ Scholars who approach the text from a diachronic perspective often used these discrepancies to look for seams in the text. ${ }^{8}$ Two examples of more suspicious readings would be McKenzie (1991) and White $(1994,1997)$; both readings pre-date the discovery of the Tel Dan inscription and in both the discrepancies between the vineyard story and Jehu's justification for killing Joram play an important role (McKenzie 1991:73; White 1994:67).

McKenzie (1991:66-80) offers a detailed discussion of the different oracles against the house of Ahab. He does not think that the story of Naboth's vineyard and the rebellions of Jehu initially had anything to do with each other. McKenzie (1991:78-79) identifies at least two layers in these narratives, one added by what he calls the Dtr and one added later. ${ }^{9}$ It is also clear to McKenzie (1991:80) that with regard to 2 Kings

6.See, for instance, the discussion in Otto (2001:97-100), who sums up the more traditional historical arguments and then (2001:101-110) shows how the discovery of the Tel Dan inscription made it clear that the story was meant as 'advertising' (Werbung) for Jehu's revolution. One wonders why she sticks to the term 'revolution'?

7.Quite a few scholars have listed and discussed these discrepancies. See, for instance, Rofé (1988:95-96), McKenzie (1991:73), White (1994:67-68, 1997:17-18), or more recently, Russell (2014:458-459).

8.For a good description of how source critics go about their task, see the more recent book by McKenzie (2010:29-31).

9.The following texts are all part of his Dtr-layer: 2 Kings 9:7a, 8-9, 15a, 16aa, 25-26 $36 a, 37 ; 10: 1 a, 10-17,29-36$. To the post-Dtr layer belong: $9: 7 b, 10 a, 14,15 a, 16 a \beta$ $27 \mathrm{~b}-29,36 \mathrm{~b} ; 10: 18-28$.
9-10 some source text had been received and reworked. Yet, the link between the story of Naboth's vineyard and the rebellion of Jehu was only made by the Dtr with the following purpose, according to McKenzie (1991):

He linked it [i.e. the Jehu story] with the Naboth episode as the fulfillment of Elijah's oracle against Ahab's house and incorporated the product within his prophecy - fulfillment scheme. ... The only difference in the case of Ahab's house was that Dtr had access to a lengthy narrative about Jehu's coup which he incorporated within his scheme as the fulfillment of Elijah's word which he set in the context of the Naboth incident. (p. 79)

Thus, the larger purpose for the Dtr was to honour his prophecy-fulfilment scheme and therefore he linked the stories of Naboth with the rebellion of Jehu. One obvious result of such an interpretation is that the idea that Jehu's rebellion could have been about restitution disappears. This link was made by the author and/or editor who linked the two stories only much later, after everything had transpired.

Although earlier scholars usually assumed that 'an historical Elijah existed more or less in conformity to the legends (minus the supernatural elements), and certainly in opposition to Ahab and Jezebel' (White 1997:1), White (1997:77) argues that the Elijah legends were created after Jehu's rebellion to legitimise his usurpation of the throne. She obviously presents a more complex argument to which we cannot do justice, but the following comments will suffice to make the point. White $(1994: 69,1997: 38)$ thinks that 2 Kings 9:25b-26a are the earliest verses in the tradition of Ahab's crime. To legitimise the coup by Jehu, the rest of the narrative is then basically created along with 1 Kings 21 . The latter has a lot in common with the David and Bathsheba story of 2 Samuel 11-12 (White 1997:17-24). Thus, Elijah is portrayed as a second Nathan. One difference between White and McKenzie is that although he thinks the Jehu and Naboth stories existed separately and were only later united, she thinks both stories were created as one unit from the start, albeit a very fictional story, which was produced to legitimise Jehu's coup.

These are just two examples of scholars who used the basic tools of diachronic studies to question the veracity of the story about the rise of Jehu. They both differ from a longer list of earlier scholars who accepted the basic story presented by the text. ${ }^{10}$ Next, we will provide a brief overview of the debate on the Tel Dan inscription, before we return to the recent debates on the history of Ancient Israel.

\section{The Tel Dan inscription: Text and possible author}

During excavations in 1993 in Tel Dan by the excavator and the epigrapher, Avraham Biran and Joseph Naveh, a basalt stone that appeared to be a fragment of a large monumental inscription was discovered; this led to a publication in the same year (Biran \& Naveh 1993). This discovery was made 10. See footnote 4 . 
on 21 July. The stone, which was thought to be a fragment of a large stone, was found in the secondary remains of a wall bordering the eastern section of a large pavement or piazza at the entrance to the outer gate of the city of Dan (Biran \& Naveh 1993:81). The discovery of this inscription triggered a controversial debate around the phrase bytdwd in line 1.9 and the fact that it could be interpreted as 'House of David' (see, e.g., Kottsieper 2007:104). However, we are not interested in that debate, but rather in what was written on the fragment discovered next.

On 20 June 1994, two further fragments were found and published by Biran and Naveh, and were designated as fragments B1 and B2 (Biran \& Naveh 1995:1), with the earlier one, found in 1993, now becoming fragment A. Biran and Naveh (1995:10-12) argued that fragments B1 and B2 should be joined to the left of fragment A. Although there has been a lot of debate about the way in which they linked these fragments, there, currently, seems to be a majority view that their initial interpretation from 1995 is the most probable one. ${ }^{11}$

The language of the inscription is Early Aramaic with the letters clearly engraved; however, the small letters comprise only a small part of the text, making reconstruction tentative (Biran \& Naveh 1993:87). Fragments A and B1 and B2 (in italics below) when combined, as constructed by Biran and Naveh (1995:13), read as follows in English:

1. $[\ldots . .$.$] and c u t[\ldots]$

2. [...] my father went up [against him when] he fought at [...]

3. And my father lay down, he went to his [ancestors] (viz. became sick and died).

4. And the king of I[s-]rael entered previously in my father's land. [And] Hadad made me king.

5. And Hadad went in front of me, [and] I departed from [the] seven [...-]

6. s of my kingdom, and I slew [seve]nty kin[gs], who harnessed thou[sands of

7. cha-]

8. riots and two thousand horsemen (or horses). [I killed Jeho]ram son of [Ahab]

9. king of Israel, and [I] killed [Ahaz]iahu son of [Jehoram kin-]

10. $\mathrm{g}$ of the House of David. And I set [their towns into ruins and turned]

11. their land into [desolation]

12. other [... and Jehu ru-]

13. led over Is $[$ rael... and I laid]

14. siege upon $[\ldots]$

For our purposes, the references in fragment B1 and B2 to the killing of the king of Israel and the king of Judah are the most relevant. Stith (2008) sums up the 'episodes' as follows:

(a) The author's father fought with an enemy, perhaps at Abel (lines 1-2), (b) The father died (3a), (c) The king of Israel invaded the father's land $(3 b-4 a)$, (d) Hadad enthroned the author

11.For a fairly detailed summary of this debate, see, for instance, Schniedewind (1996:77), Kottsieper (2007:103-108), Robker (2012:240-246), or more recently Frevel (2016:110). All follow Biran and Naveh (1995). Scholars who disagree include scholars such as Galil (2001) and Athas (2003). For Galil (2001:18) fragment B actually precedes A, whereas Athas (2003:175-191) argues for the other way around. (4b-5a), (e) With Hadad's help, the author killed two 'mighty kings', Joram of Israel and Ahaziah of Judah, despite their military power (5b-9a), (f) The author visited destruction on the territory of his opponents (9b-11a), (g) A new king, here reconstructed as Jehu, was enthroned in Israel (1 lb-12a), (h) Some kind of siege took place (13). (p. 43)

Joram of Israel and Ahaziah of Judah are probably the same kings presumably killed by Jehu in 2 Kings 9, so now the pertinent question is who wrote this inscription in Aramaic claiming the death of these two kings? Although there has been a lot of debate around this issue and, although even Biran and Naveh have changed their minds about it, ${ }^{12}$ most scholars now seem to argue for Hazael. We read about him in 2 Kings 8 where he is portrayed as a usurper, albeit at the instigation of the prophet Elisha. The list of scholars who hold this view is fairly long. ${ }^{13}$ The question that then follows is: if Hazael claims that he killed the two kings and the narrative of 2 Kings 9-10 claims that Jehu did it, then what is going on? Who killed the kings? Is it either Jehu or Hazael, or were they somehow working together?

Quite a few scholars have argued for the latter case (e.g. Schniedewind 1996). This means that there was a coalition between Jehu and Hazael. Some scholars, such as Na'aman (2000), have objected to this view and would rather argue that because the Tel Dan inscription is the older text, he would rather attribute the deaths to Hazael. Yet, Frevel (2016:216-217) reminds us that both 2 Kings 10 and the Tel Dan inscription are 'tendenziös, von Propaganda durchzogen und sicher kein getreues Abbild historischer Geschehnisse'. He then settles for the view that Hazael supported the coup by Jehu, which means that behind the coup one should look for 'the pragmatic politics of the military'. It also seems clear from the Black Obelisk that whatever initial alliance there might have been between Jehu and Hazael, it did not last long because Jehu soon became a vassal of Shalmaneser III. The point that we are aiming to establish is that in this interpretation there is not much room left for retributive justice or some quest for a purer Yahwism. Jehu's coup was simply about getting hold of power, more an ancient Game of Thrones than anything else.

We have seen until now that one could question the aspect of retributive justice, mostly on diachronic grounds, because the links between Jehu's coup and 1 Kings 21 were made later, but from a purely historical perspective the arguments about Yahwism and Jehu pursuing Yahwism of a purer kind also seem rather farfetched now. In the next part of the article, we will thus engage with two more recent engagements with the history of Yahwism. Both scholars are from the German-speaking world, although the book by Römer was first published in French.

12.After the initial publication of fragment A, Biran and Naveh (1993:96) argued for Ben-Hadad I, but after the discovery of fragment B, they argued for Hazael (Biran \& Niveh 1996:18).

13.As an example of those who agree on Hazael, the following list would do: As an example of those who agree on Hazael, the following list would do:
Schniedewind (1996:75), Knauf (2000:59), Na'aman (2006:160), Kottsieper Schniedewind (1996:75), Knauf (2000:59), Na'aman (2006:160), Kottsieper
(2007:119), Stith (2008:88), Robker (2012:265), Frevel (2018:110). See also the older list provided by Becking (1999:188 n.6). 


\section{The history of YHWH}

Römer's (2015) book is essentially a history of YHWH. He provides an overview of the way that many scholars currently think about the origins of $\mathrm{YHWH}$. We do not need to go into detail because we will focus on his interpretation of Jehu's coup in order to juxtapose that with Frevel's view below. Although Römer (2015:104-123) presents a very critical understanding of the origins and $\mathrm{YHWH}$, and does not shy away from addressing critical issues such as Asherah, his understanding of Jehu's coup is fairly sympathetic towards Jehu.

Römer (2015:104) accepts that the final story is told by southern scribes who did not like the Northern kings. For Römer it is also very clear that the YHWH, who was served in the North, was different from the one in the South. In the North, the exodus tradition was more important, as is seen in 1 Kings 12, when Jeroboam initiates the cult of the North. Although some scholars think that this might only have happened during the time of Jeroboam II, who was a descendent of Jehu, it is clear that the YHWH of the exodus was worshipped in both sanctuaries of Bethel and Dan (Römer 2015:108). Furthermore, Römer (2015:109) argues that YHWH probably had a parhedros like Asherah and he was worshipped in the shape of a bull, as was Baal at Ugarit. Also, there probably was a sanctuary at Samaria. Römer (2015:111) thinks that Omri (and Ahab) would have favoured the cult of Phoenician Baal, but would also have provided space for a cult of YHWH. Römer (2015:115) also (like Frevel) engages with the Mesha inscription, and argues that it is clear from this text that YHWH was worshipped by the Israelites in Transjordan at Nebo at 'an official royal sanctuary of Yhwh'. For Römer (2015:116), YHWH was worshipped as a 'baal' and a storm god.

Regarding Omri's alliance with the Phoenicians, Römer (2015:177) argues that this was done by marrying Ahab to Jezebel. He thinks that what the book of Kings portrays as the worship of Baal was probably more the worship of Melqart of Phoenicia, who was the tutelary god of Tyre where Jezebel was from. Like McKenzie, ${ }^{14}$ Römer (2015:118) also thinks that the stories of the prophets Elijah and Elisha were added later. In the final text, the stories of the struggle of Elijah against the Baal prophets become a prelude to Jehu's violent tale. Römer (2015) puts it as follows:

We might also imagine that there was a rivalry in the kingdom of Israel between Bethel (Yhwh) and Samaria (Melqart or a 'Phoenician Baal'), up until the putsch by Jehu, which definitely imposed Yhwh as the national god and the titular deity of the kings. (p. 120)

This interpretation by Römer is actually very close to the more traditional interpretations listed earlier by White (see footnote 4). Römer's argument is much more critical and nuanced, but still, for him, Jehu did bring about some change in Yahwism.

14.See McKenzie (1991:81-100).
Although in Römer's interpretation it is still possible to see some motive for purer Yahwism in the rebellion of Jehu, recently Frevel (2018) has presented a far more radical argument, which paints a darker picture (if one is concerned with the violence in the text). In Frevel's (2018:24-31) understanding, Omri was actually the person who introduced Yahwism into the Northern Kingdom. His argument is based on the names of the characters in the biblical text itself, names that are confirmed by extra-biblical texts. Like Römer, Frevel (2018:24) also engages with the Mesha inscription, which he (like others) dates to the second-half of the 9th century, and for Frevel it is important to point out that Mesha is the oldest extra-biblical text that links YHWH to Israel and this occurs during the time of the Omrides. He also engages with the Tel Dan inscription, where both kings Joram and Ahaziah are mentioned. Both have the theophonic element of 'yah/yahu' in their names and both, according to Frevel, are brothers and Omrides. ${ }^{15}$ Thus, two extra-biblical texts link the worship of YHWH with the time of the Omrides. None of the other 'bad' kings before the Omrides have elements of $\mathrm{YHWH}$ in their names (Frevel 2018:30). Yet, here you have Joram (Jehoram), Ahaziah and even Athaliah, all probably children of Ahab, the big enemy of Yahwism, according to the narrative of 2 Kings, but his children's names are proudly Yahwist. The same is also true of Jehu himself, whose name means ' $\mathrm{YHWH}$ it is', but if you were to look exclusively at the evidence of the names, you have one person with a Yahwist name killing others with Yahwist names. In short, for Frevel (2018), the Omrides made YHWH into the dynasty god, not Jehu:

YHWH wird vielleicht schon von Omri, spätestens aber mit Ahab programmatisch zum Dynastiegott im sich formierenden Staat 'Israel' erhoben. (p. 35)

Frevel (2018:37) himself acknowledges that there is a lot of speculation in his argument, but still the extra-biblical evidence allows him to do this. Yet, it should be obvious that this interpretation is totally different from Römer's, and it does not really offer any explanation for why Jehu then wanted so much to destroy the Omrides, apart from the fact that he wanted the throne, which seems like the most obvious explanation, but there is not much left of the rationales that these were quests for retributive justice or purer Yahwism.

The important question would then be: why did the authors / editors of the narrative of Jehu's putsch go to such great (literary) lengths to portray him as righteous?

\footnotetext{
15. Elsewhere Frevel (2016:204-208) argues this point in much more detail. His basic argument is that during the period of Omride rule in Israel, Judah was either under argument is that during the period of Omride rule in Israel, Judah was either under
the influence of the Omrides, or ruled by them directly. For him this is the only way the influence of the Omrides, or ruled by them directly. For him this is the only way
to make sense of a very confusing narrative in 2 Kings about the succession of

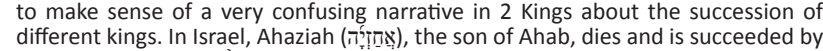

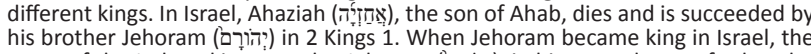
name of the Judean king was also Jehoram (ירוֹ was the son of Jehoshaphat (2 Ki 1:17). Yet, later in 2 Kings 3:1 it says that Jehoram of Israel became king when Jehoshaphat was still in his 18th year and in 2 King 8:16 it is said that Jehoram (יהורם) became king of Judah when Joram (now spelled 8il') king of Israel was in his 5th year. Then, according to 2 Kings 8:25, in the 12th year of Joram of Israel, Ahaziah (אידיה) succeeded his father Jehoram in Judah. These two, Ahaziah of Judah and Joram of Israel, were then killed by Jehu (or These two, Ahaziah of Judah and Joram of Israel, were then killed by Jehu (or Hazael). This Ahaziah is spelled slightly differently from the earlier Ahaziah of srael, but it should be clear that in both the North and in the South we had king called Joram or Jehoram and Ahaziah. Frevel (2016:205-207) thinks that they were rothers, sons of Omri, who ruled over the two kingdoms. Joram started as coregent with Jehoshaphat and was later moved to Israel, while his brother then moved to Judah. This interpretation obviously explains why Jehu killed them both He was cleaning up the house of Omri, after all.
} 


\section{Justifying violent acts}

Why do people want to justify violence? This is obviously also a question asked by modern-day scholars. Thus, Uniacke (2000:64) in her article on why revenge is wrong argues that: 'The infliction of injury to another person requires moral justification: it is wrong in the absence of some justifying rationale'. Although this is a modern-day perspective, it is fascinating that the ancient editors/authors of 2 Kings 9-10 clearly shared a similar view. They wanted to justify Jehu's murder spree.

Contemporary debates about 'capital punishment' also seem to provide useful categories. Thiroux and Krasemann (2012:171) define capital punishment as the infliction of death for certain crimes'. The definition of these crimes often depends on the societies in question, and the crimes vary. The two crimes that the authors 'created' for the Omrides were worshipping Baal (i.e. idolatry) and the murder or unjust death of Naboth and his family.

Thiroux and Krasemann (2012:171) document three major theories of capital punishment as follows:

- Retributive: Punishment should be given only when it is deserved and only to the extent it is deserved. It should have no other goal than punishing people who deserve the punishment because of some immoral act that they committed, and the punishment should fit the crime. It should be clear that the story of Jehu's coup has this element. The Omrides had it coming, according to the story, at least.

- Utilitarian: Punishment should always have as its aim the good of society. If punishment will bring about good consequences for people, then it should be applied; if it would not, then it should not. It should always be given in order that some good can be done - for example, to deter future crime, to protect society or to rehabilitate criminals. This element is especially present with regard to the portrayal of Yahwism in Israel. The story presents Jehu as one whose motive is to create a purer form of Yahwism that moves further away from idolatry. In the larger narrative of the $\mathrm{DH}$, Israel and Judah served other gods and that led to the catastrophes of $722 \mathrm{BCE}$ and 582 BCE. Jehu, for the sake of the common good of Israel, tried to lead them on another path.

- Restitution (compensation theory): Justice is served only if the victims of a crime or offence are provided with restitution or compensation for the harm done to them. This element is lacking in the story. As Mtshiselwa (2014:206) has pointed out, there is no restitution for the possible descendants of Naboth. They never get the farm in the Jezreel Valley back.

However moral they may be, these punishments contradict the contemporary principle of the inviolable value of life. Hill (2010:75-77) uses the notion of the 'just war theory' that provides the criteria to judge the rightness of serious acts of political (religious) violence, and a structure to support these acts (who can do it, what the limits are, and so on). The 'just war theory' addresses both the reasons for going to war (usually called jus ad bellum) and conduct in war (jus in bello) in the following principles:

\section{Jus ad bellum:}

1. The war must be fought for a just cause.

2. It should be fought for that reason and not for ulterior motives; the right attitude is necessary.

3. There should be proportionality - the good to be achieved should not be outweighed by the harm that will be done. There must be a reasonable hope of success.

4. The appropriate legitimate authority should make the decision.

5. There must be a formal declaration of war.

6. The war should be the last resort.

Jus in bello:

1. The requirement of non-combatant immunity.

2. Proportionality.

We are obviously applying contemporary values to an ancient text, but even with the narrative as it is, Jehu would dismally fail the two criteria for jus in bello. The sons of Jehu were non-combatants and things did not turn out well for them. The story reflects no sense of proportionality either. With regard to principles 4-6 of jus ad bellum, the narrative does not paint a pretty picture. Jehu is a usurper who only plays his hand at the appropriate moment. With principles $1-3$, there is something at least to debate. With regard to 3 , yes, Jehu is successful, but the rest of the narrative is clear about the decline of Israel afterwards. The editors of the story seem to be somehow concerned with principles 1 and 2 . They provide Jehu with at least two just causes, namely, retributive justice and the quest for a purer Yahwism. Add to that the support of the prophet Elisha and it seems that Jehu has the 'right attitude', but as soon as critics such as McKenzie and White examine the text more critically, then it seems that these causes were added later. It becomes much clearer with the discovery of the Tel Dan inscription and the interpretation that Jehu and Hazael were in cahoots that Jehu did not really have pure motives, but was probably simply more interested in acquiring power. About the quest for a purer Yahwism, if we follow the more traditional interpretation of Römer, then there could have been some Yahwistic motive. If we follow Frevel, then that rationale also disappears because now the Omrides become the true Yahwists.

\section{Conclusion}

But what are we to make of this violent story? One positive aspect seems clear. The editors of this story were probably also uncomfortable with the violence in the story. That is why they told it in such gory detail and why they clearly tried to justify the violence by covering it up with 'just causes'. It is clear after a critical engagement with the text and an extrabiblical text such as Tel Dan that their 'cover-up' was not very convincing, but at least they tried. Yet, even if Jehu was 
motivated by Yahwism and justice (which he clearly was not), would that really have helped to somehow make the violence more palatable? For the modern-day reader, the answer is clearly 'no', but it might have worked for an ancient reader.

Jehu's coup is undeniably a single event interpreted differently from different historical contexts. Yet, for contemporary readers violence cannot be justified, as it contradicts the principle of the right to life. In our own world, religion still plays a very negative role of instigating violence. The tools provided by historical criticism, which include engagement with extra-biblical texts, at least help us to identify ideologies and power struggles in the ancient text. What presents itself as a quest for a purer religion is actually a quest for power. It is not difficult to identify similar situations in our current context.

\section{Acknowledgements Competing interests}

The authors declare that they have no financial or personal relationship(s) that may have inappropriately influenced them in writing this article.

\section{Disclaimer}

The views expressed in this article are that of the authors and not an official position of the University of Pretoria, Ruhr Universität Bochum, the Deutscher Akademischer Austauschdienst or the NRF.

\section{Authors' contributions}

L.L.D.M. and E.E.M. equally contributed to the research and writing of this article.

\section{References}

Athas, G., 2003, The Tel Dan inscription: A reappraisal and a new interpretation Journal for the Study of the Old Testament Supplement Series 360, Sheffield Academic Press, London.

Becking, B., 1999, 'Did Jehu write the Tel Dan inscription?', Scandinavian Journal of the Old Testament 13(2), 187-201.

Biran, A. \& Naveh, J., 1993, 'An Aramaic stele fragment from Tel Dan', Israel Exploration Journal 42(2/3), 81-98.

Biran, A. \& Naveh, J., 1995, 'The Tel Dan inscription: a new fragment', Israel Exploration Journal 45(1), 1-18.

Frevel, C., 2016, Geschichte Israels, Kohlhammer, Stuttgart.
Frevel, C., 2018, 'Selbst Gott hat eine Geschichte. Vom Vergessen der Geschichte und der Notwendigkeit einer geschichtlichen Dimension in der Exegese - am Beispiel der Frühgeschichte des Gottes Israels', in G. Essen \& C. Frevel (eds.), Theologie der Geschichte - Geschichte der Theologie, Quaestiones Disputatae 294, pp. 10-39, Geschichte - Geschichte
Herder Verlag, Freiburg.

Galil, G., 2001, 'A re-arrangement of the fragments of the Tel Dan inscription and the relations between Israel and Aram', Palestine Exploration Quarterly 133(1), 16-21. https://doi.org/10.1179/peq.2001.133.1.16

Hill, H., 2010, 'Can just war theory survive the war on terror?', Journal of the Institute of Justice and International Studies 10(1), 77-86.

Knauf, E.A., 2000, 'Filling in historical gaps: How did Joram really die? Or, the invention of militarism', Biblical Interpretation 8(1), 59-69. https://doi.org/ $10.1163 / 156851500300046682$

Kottsieper, I., 2007, 'The Tel Dan inscription (KAI 310) and the political relations between Aram-Damascus and Israel in the first half of the first millennium $B^{\prime} E^{\prime}$, in L.L. Grabbe (ed.), Ahab Agonistes: The rise and fall of the Omri Dynasty, Library of the Hebrew Bible/Old Testament Studies Supplement Series 421, pp. 104-134, T \& T Clark, London.

Lamb, D.T., 2007, Righteous Jehu and his evil heirs: The Deuteronomist's negative perspective on dynastic succession, Oxford University Press, New York.

McKenzie, S.L., 1991, The trouble with Kings. The composition of the Book of Kings in the Deuteronomistic history, Brill, Leiden.

McKenzie, S.L., 2010, Introduction to the Historical Books. Strategies for Reading, Eerdmans, Grand Rapids, MI.

Meyer, E.E., 2011 'The role of the Old Testament in a violent world', Verbum etEcclesia 32(2), Art. \#502, 1-8. https://doi.org/10.4102/ve.v32i2.502

Mtshiselwa, N., 2014, 'A re-reading of 1 Kings 21:1-29 and Jehu's revolution in dialogue with Farisani and Nzimande: Negotiating socio-economic redress in South Africa', Old Testament Essays 27(1), 205-230. https://doi.org/10.4102/hts.v74i1.5017

Na'aman, N., 2000, 'Three notes on the Aramaic inscription from Tel Dan', Israel Exploration Journal 50(1/2), 92-104.

Na'aman, N., 2006, 'The story of Jehu's Rebellion: Hazael's inscription and the Biblical narrative', Israel Exploration Journal 56(2), 160-166.

Otto, S., 2001, Jehu, Elia und Elisa. Die Erzählung von der Jehu-Revolution und die Komposition der Elia-Elisa-Erzählungen, Kohlhammer, Stuttgart.

Robker, J.M., 2012, The Jehu Revolution: A royal tradition of the Northern Kingdom and its ramifications, BZAW 435, De Gruyter, Berlin.

Rofé, A., 1988, 'The vineyard of Naboth: The origin and message of the story', Vetus Testamentum 38(1), 89-104. https://doi.org/10.1163/156853388X00517

Römer, T., 2013, 'Deuteronomistic history', in D.C. Allison, C. Helmer, C.-L. Seow, H. Spieckermann, B. DovWalfish \& E. Ziolkowski (eds.), The Encyclopedia of the Bible and its reception, vol. 6, pp. 648-653, De Gruyter, Berlin.

Römer, T., 2015, The invention of God, Harvard University Press, London.

Russell, S.C., 2014, 'The hierarchy of estates in land and Naboth's Vineyard', Journal for the Study of the Old Testament 38(4), 453-469. https://doi. org/10.1177/0309089214536489

Scheffler, E., 2014, 'Reflecting on (non-)violence in the book of Deuteronomy in (Old Testament) canonical context', Old Testament Essays 27(2), 579-596.

Schniedewind, W.M., 1996, 'Tel Dan Stela: New Light on Aramaic and Jehu's Revolt', Bulletin of the American Schools of Oriental Research 302, 75-90.

Stith, M.D., 2008, The coups of Hazael and Jehu: Building an historical narrative, Gorgias Press, Piscataway.

Thiroux, J.P. \& Krasemann, K.W., 2012, Ethics: Theory and practice, 11th edn., Pearson, Boston, MA.

Uniacke, S., 2000, 'Why is revenge wrong?', The Journal of Value Inquiry 34(1), 61-69. https://doi.org/10.1023/A:1004778229751

White, C.M., 1997, The Elijah Legends and Jehu's Coup, Brown Judaic Studies 311 Scholars Press, Atlanta, GA

White, M., 1994, 'Naboth's vineyard and Jehu's coup: The legitimation of a dynastic extermination', Vetus Testamentum 44(1), 66-76. https://doi.org/10.1163/ 156853394X00060 